\title{
ОСОБЕННОСТИ МИКРОЭЛЕМЕНТНОГО СОСТАВА У ДЕТЕЙ С ОЖИРЕНИЕМ
}

\author{
Н.В. Болотова , Н.Ю. Филина, Е.А. Петрухина, Н.А. Николаева, А.А. Акопян \\ Саратовский государственный медицинский университет им В.И. Разумовского Минздрава России, \\ Россия, г. Саратов, ул. Б.Казачья, 112, 410012 \\ *e-mail: kafedranv@mail.ru
}

РЕЗЮМЕ. В современном мире проблема ожирения имеет повсеместную распространенность, в том числе и среди детского населения. В исследовании была проведена оценка рационов питания, по результатам которой выявлено нерациональное потребление продуктов. Дети употребляли пищу с избыточным содержанием жиров и недостаточным количеством белка, овощей и фруктов, что приводило к ожирению. В связи с этим изучен микроэлементный состав организма детей для перспектив последующей коррекции.

КЛЮЧЕВЫЕ СЛОВА: микроэлементы, питание, продукты, рацион, дети, дисбаланс, ожирение.

\section{SPECIFICITIES OF TRACE ELEMENTS IN CHILDREN WITH OBESITY}

\author{
N.V. Bolotova*, N.Yu. Filina, E.A. Petrukhina, N.A. Nikolaeva, A.A. Akopyan \\ Saratov State Medical University named after V.I. Razumovsky, city of Saratov, st. BolshayaSadovaya 112, 410012 \\ *e-mail: kafedranv@mail.ru
}

ABSTRACT. Obesity is spreading rapidly in the modern world, especially among children. We were analyzed different compositions of diets and as a results we searched irrational food in the diets. These food include excess of fats, low in proteins and not enoughvegetables and fruits that leeds to obesity in childhood. Nutrient analysis is relevant because it creates possibiliities of correction for health in the future.

KEYWORDS: trace elements, nutrition, food, diet, children, imbalance, obesity.

\section{ВВЕДЕНИЕ}

В настоящее время проблема ожирения является актуальной, поскольку данная патология приобрела характер эпидемии (World Health Organization..., 2018). При изучении питания детей, страдающих ожирением, был выявлен крайне несбалансированный рацион (с избыточным содержанием жиров, дефицитом белков и очень низким потреблением овощей и фруктов) (Болотова и др., 2016). Микронутриенты поступают в организм главным образом с продуктами питания. Учитывая нерациональное питание детей с ожирением, считаем актуальным изучение содержания микроэлементов в их организме (World Health Organization..., 2004; Итоговый доклад..., 2018), поскольку микроэлементы участвуют в формированииметаболитного статуса.

Цель работы - изучить особенности микроэлементного состава организма у детей с ожирением.

\section{МАТЕРИАЛЫ И МЕТОДЫ}

Обследовано 20 детей с экзогенно-конституциональным ожирением в возрасте 9-17 лет; из них 6 мальчиков и 14 девочек. У детей изучали жировой и углеводный обмены, вычисляли индекс массы тела и коэффициенты стандартного отклонения. Микроэлементный статус определяли методом массспектрометрии волос в АНО «Центр биотической медицины» (Москва).

\section{РЕЗУЛЬТАТЫ И ОБСУЖДЕНИЕ}

Среди обследуемых в основном встречались сочетанные микроэлементозы (100\% случаев). У одного пациента отмечалась комбинация микроэлементов (снижение калия, натрия, марганца, йода, кобальта) и дефицита витамина D.

У детей младшего школьного возраста (8 человек в возрасте 9-11 лет) в основном наблюдался дефицит натрия, калия и марганца. У детей старшего школьного возраста выявлено усугубление дисбаланса микроэлементов: йода, кальция, кобальта, меди, цинка и других микронутриентов (причем повышенное содержание кальция, магния, марганца и меди - у 8 пациентов, цинка - у 4), что связано с 
избыточным выведением их из организма. Наиболее выраженные изменения встречались по следующим микроэлементам: дефицит марганца выявлен в 70\% случаев, калия и натрия - у $40 \%$ пациентов, йода, кремния, кобальта, молибдена - в $20 \%$ случаев, тенденция к снижению уровня магния, селена, фосфора и хрома обнаружена у $10 \%$ детей.

Нижняя граница нормы ряда микроэлементов, таких как йод, кобальт (60\% случаев), калий (30\%), магний, натрий (20\%) и железо, кремний, натрий (10\%), отмечалась среди меньшего числа пациентов.

\section{ВЫВОДЫ}

Несмотря на превышение калорийности пищевого рациона (при дефиците овощей и фруктов) отмечался выраженный дисбаланс микроэлементов, что указывает на необходимость их коррекции не только путем нормализации диеты, но и восполнения эссенциальных микроэлементов.

\section{Список литературы}

1. Болотова Н.В., Матвеева Н.Н., Абдуразакова А.О. Клиническая картина пациентов с микроэлементозами за 2014-2015 гг. в г.Саратов. Bulletin of Medical Internet Conferences. 2016; 6(5): 808.

2. Итоговый доклад о результатах и основных направлениях деятельности Федеральной службы по надзору в сфере защиты прав потребителей и благополучия человека в 2017 году. М. 2018; с. 3, 14.

3. World Health Organization; Noncommunicable Diseases (NCD); Country Profiles, 2018; 9-23.

4. World Health Organization and Food and Agriculture Organization of the United Nations. Vitamin and mineral requirements in human nutrition. Second edition; 2004; WHO Library Cataloguing-in-Publication Data; Chapter 1.2.6, p.4.

\section{References}

1. Bolotova N.V., Matveeva N.N., Abdurazakova A.O. Klinicheskaya kartina pacientov s mikroelementozamiza 2014-2015 gg. V g. Saratov. Bulletin of Medical Internet Conferences2016; 6(5): 808.

2. Itogovyj doklad o rezul'tatah i osnovnyh napravleniyah deyatel'nosti Federal'noj sluzhby po nadzoru $\mathrm{v}$ sferezash chityprav potrebitelej i blagopoluchiya cheloveka v 2017 godu. Moscow. 2018; p. 3, 14.

3. World Health Organization; Noncommunicable Diseases (NCD); Country Profiles, 2018;9-23.

4. World Health Organization and Food and Agriculture Organization of the United Nations. Vitamin and mineral requirements in human nutrition. Second edition; 2004; WHO Library Cataloguing-in-Publication Data; Chapter 1.2.6, p.4. 